\title{
Diskurser om undervisning med digitala verktyg: En kritisk granskning av relationen mellan universitetslä- rares beskrivningar och lärosätens styrdokument
}

\author{
Marita Ljungqvist \\ Lunds universitet
}

\begin{abstract}
Syftet med denna studie är att undersöka och jämföra hur undervisning i digitala miljöer konstrueras, dels i reflekterande texter skrivna av universitetslärare som deltog i en högskolepedagogisk kurs 20I7-20I8, dels i styrdokument om e-lärande från svenska lärosäten. Resultatet visar att lärarnas och styrdokumentens diskurser emellanåt står i kontrast till varandra. Medan de senare såväl explicit som implicit uttrycker ett antagande om att undervisning med digitala verktyg är effektiv och tidsbesparande pekar lärartexterna exempelvis på att det förberedande arbetet är tidskrävande. I styrdokumenten beskrivs också undervisningens digitala utveckling som oundviklig och positiv medan lärarna ger uttryck för ett mer komplext, kritiskt och eftertänksamt förhållningssätt.
\end{abstract}

\section{INTRODUKTION}

I artikeln Minding our language: why education and technology is full of bullshit... and what might be done about it (2015) beskriver Selwyn det offentliga samtalet kring digitaliseringen av utbildning som okritiskt, överdrivet optimistiskt och närmast evangeliserande. Även Munros (20I7) analys av ett flertal brittiska policytexter kring e-lärande pekar på att dessa i hög grad ger uttryck för en naivt positiv och deterministisk syn på digital utbildningsteknologi, medan få studier kan peka på tydliga kausala samband mellan användningen av digitala verktyg och förbättrat lärande (Clegg, Hudson \& Steel, 2003; Munro, 2017; Selwyn, 20II). Målgruppen för flertalet studier inom området är främst praktiserande lärare där syftet är att demonstrera "vad som fungerar" samtidigt som de ofta saknar vetenskaplig förankring (Bulfin, Henderson, Johnson \& Selwyn, 20I4). Bigum, Bulfin och Johnson (2015) menar att forskningen inom fältet domineras av normativa studier som utgår ifrån att teknik kan användas för att förbättra lärande. De efterfrågar därför kritiska studier som problematiserar och ifrågasätter dessa förgivettaganden och breddar kunskapen inom fältet.

Diskursen om studentcentrerat lärande utgör en del av den förändrade pedagogiska praktik som tidsmässigt sammanfallit med den digitala utvecklingen inom högre utbildning. Studenter konstrueras i denna diskurs som självständiga - vilket samtidigt i hög grad frigör lärosätena från ansvar och skyldigheter mot dem - och digital teknologi konstrueras som en lösning som ska leda till större studentengagemang (Clegg et al., 2003). I praktiken används dock digitala system och verktyg ofta för att kopiera traditionell undervisning, för ren informationsöverföring eller administrativa uppgifter kopplade till utbildning (Blin \& Munro, 2008; Gouseti, 20ı;; Munro, 20I7; Price \& Kirkwood, 20I4). Hittills har forskningen visat att få lärare vänder sig till vetenskaplig litteratur för att få stöd i beslut som de gör när det gäller nätbaserad undervisning

*Författarkontakt: marita.ljungqvist@ahu.lu.se

Artiklar och reflektioner är kollegialt granskade. Övriga bidragstyper granskas av redaktionen. Se www.hogreutbildning.se ISSN 2000-7558

(C)2018 Marita Ljungqvist. This is an Open Access article distributed under the terms of the Creative Commons Attribution-NonCommercial 4.0 International License (https://creativecommons.org/licenses/by-nc/4.0/), allowing third parties to share their work (copy, distribute, transmit) and to adapt it, under the condition that the authors are given credit, that the work is not used for commercial purposes, and that in the event of reuse or distribution, the terms of this license are made clear.

Citation: Marita Ljungqvist (2018) «Diskurser om undervisning med digitala verktyg: En kritisk granskning av relationen mellan universitetslärares beskrivningar och lärosätens styrdokument», Högre utbildning, 8(2), 90-103. http://dx.doi.org/10.23865/hu.v8.1343 
(Price \& Kirkwood, 20I4), och att de känner oro för negativa konsekvenser som ökad arbetsbelastning, försämrad kvalitet på undervisningen, förlorad rätt till det egna materialet och otillräcklig teknisk kompetens (Lloyd, Byrne \& McCoy, 20I2). Dessutom associeras nätbaserad undervisning ofta med en lägre status jämfört med klassrumsundervisning (Erlanson, Helgason \& Henning, 2015; Johnson, 20I2; Ubell, 2016). Mot denna bakgrund efterfrågar Englund, Olofsson och Price (20I7) fler studier som undersöker samband mellan kontextuella faktorer och lärares förändrade förhållningssätt till att undervisa med digitala verktyg. För att på sikt kunna fånga förändringar i lärares förhållningssätt till digital undervisning krävs emellertid kunskap om hur de resonerar och uttrycker sig i sin nuvarande kontext och hur den kontexten ser ut.

För att bidra till kritisk forskning om digital undervisning, och samtidigt lägga grunden till framtida studier av eventuella förändringar i lärares förhållningssätt till sådan praktik, är syftet med denna studie att kritiskt granska några av de diskurser som omgärdar fältet. Med fokus på lärares egna texter och styrdokument kommer följande forskningsfrågor att besvaras:

I) Hur konstrueras undervisning och utveckling av undervisning med digitala verktyg i a) lärares reflekterande utsagor om sin praktik och b) styrdokument utformade vid svenska lärosäten?

2) Hur är styrdokumentens diskurser relaterade till lärarnas diskurser om digitala verktyg i undervisningen?

Målet är att studien ska bidra till ökad kunskap om förhållandet mellan policy och praktik när det gäller undervisning och lärande med digitala verktyg.

\section{METODOLOGI}

Kritisk diskursanalys som kunskapsteoretisk ansats

Metodologin som ligger till grund för denna studie är kritisk diskursanalys. Kunskapsteoretiskt bygger diskursanalys på socialkonstruktivistiska antaganden: att vi skapar vår kunskap om den sociala verkligheten genom social interaktion, att denna kunskap är en kulturellt och historiskt präglad produkt av våra sätt att kategorisera världen och att den får konkreta sociala konsekvenser (Jörgensen, Phillips \& Vrå, 2000). Diskursanalysen är kvalitativ, tolkande och konstruktionistisk (Hardy, Phillips \& Harley, 2004, s. 19) och kan fungera både som metod och teoretisk utgångspunkt för att förstå hur språket formar och formas av sociala aktiviteter och sociala identiteter (Gee, 1999). I denna studie betraktas diskurser som framträder i lärares texter och styrdokument således som nära kopplade till social praktik genom att de interagerar med, påverkar och påverkas av den.

Inom det diskursanalytiska fältet finns det en rad olika inriktningar, däribland Faircloughs (1989, 1992, 2003) kritiska diskursanalys som tillämpats i denna studie och som riktar särskilt fokus på diskursens roll i förändringsprocesser. Analysbegreppet diskursordning inom kritisk diskursanalys betecknar en samling sätt att skapa mening inom en särskild social domän (till exempel e-lärande) vid en viss tidpunkt, framför allt genom:

- genrer (t.ex. hur man använder språket i en viss yrkesroll eller i en viss situation)

- diskurser (hur aktörer talar om - konstruerar - sociala praktiker)

- stilar (hur aktörer konstruerar identiteter) 


\section{Marita Ljungqvist}

Diskurser skapar länkar mellan språket och annan social praktik (Fairclough, 2003, s. 37) och utgör det huvudsakliga föremålet för analys i denna studie. Genom diskurser konstrueras verkligheten som den har varit, som den är eller som den skulle kunna vara och kan också materialiseras i form av nya genrer, roller, identiteter, förändringsprocesser och fysiska artefakter. Vissa sätt att skapa mening inom en diskursordning kan vara mer dominanta än andra, och några kan stå i kontrast till varandra (Fairclough, 2003, s. 206). Med kritisk diskursanalys som verktyg kan texter studeras med hänsyn till de sätt på vilka olika diskurser konstruerar den sociala verkligheten, i syfte att synliggöra sådana motsatsförhållanden och blottlägga underliggande ideologier. En ideologikritisk modell för att identifiera motsättningar mellan diskurser i olika kunskapskällor presenteras av Friesen (2008). Modellen innebär att påståenden och idéer om den sociala verkligheten som presenteras som oundvikliga och självklara i dominerande kunskapskällor granskas i förhållande till en kontext bestående av mindre inflytelserika sådana, som gör andra sanningsanspråk. Genom att jämföra diskurser i dessa olika texttyper kan kontrasterande uppfattningar och antaganden utkristalliseras som skulle kunna utgöra en början till utvecklandet av en alternativ förståelse av det fenomen som studeras.

\section{Material}

Materialet som analyserats består av texter som representerar två olika genrer. Den ena kan beskrivas som reflekterande text (Ryan, 20II). Dessa texter producerades av I5 universitetslärare i sex lärarlag som läsåret 20I7-20I8 gick en högskolepedagogisk kurs om kursdesign med särskilt fokus på blended learning som jag själv var kursledare för. Kursdeltagarna ombads vid tre tillfällen att reflektera kring digital undervisning med utgångspunkt $\mathrm{i}$ både ett pågående kursutvecklingsprojekt vid den egna institutionen och mer generella aspekter av undervisning, utifrån olika öppna frågor som exempelvis: Vilka faktorer har hittills varit drivande för upplägget av er kurs/program? Vad påverkar de beslut ni har tagit under framtagandet av detta? På vilket/vilka sätt upplever du att användning av digitala verktyg passar in/inte passar in i din övergripande syn på vad god undervisning innebär? De övergripande teman som ramade in reflektionerna var:

- Målsättningar för och syfte med digitala verktyg i den egna undervisningen

- Förutsättningar för implementering av projektet (t.ex. associationer som kan finnas kring e-lärande i den egna undervisningsmiljön, den egna pedagogiska grundsynen, den egna lärarrollen, studenternas upplevelser, underlättande faktorer)

- Process (hur arbetet i lärarlaget framskrider, vilka diskussioner som förs etc.)

Reflektionsfrågorna var formulerade på ett sådant sätt att de gjorde det möjligt för lärarna att vid varje tillfälle adressera flera teman. Sammanlagt producerade lärarna 42 texter som ingick i analysen och hädanefter kallas för lärartexter. I resultatredovisningen har lärartexterna fått koderna a-c, där $a$ betecknar lärartext som producerats vid första reflektionstillfället, $b$ är text från andra tillfället och $c$ är text från tredje tillfället.

1 Det finns ännu inte någon vedertagen svensk översättning av det engelska uttrycket blended learning. I den kurs som beskrivs här definieras denna undervisningsmodell (inspirerad av bland andra Picciano \& Dziuban, 2007) som en pedagogiskt underbyggd integrering av digitala och campusbaserade miljöer med specifika metoder för undervisning och lärande. 
Den andra typen av texter - som tillhör en styrningsgenre ${ }^{2}$ - studerades genom analys av policydokument om strategier för e-lärande från sju svenska lärosäten. Insamlingen av dessa utgick ifrån en lista som sammanställts av det nationella nätverket ITHU4 (Creelman, 20I8). Alla dokumenten fanns publicerade online och hade olika benämningar i titlarna, där e-lärandet ramades in som "vision", "strategi", "handlingsplan" eller "policy". I resultatredovisningen används styrdokument som samlingsnamn för dokumenten, medan koderna I-7 betecknar källan enligt nedanstående tabell:

\begin{tabular}{|l|l|l|c|}
\hline Inramning & Lärosäte & Dokument & Kod \\
\hline Handlingsplan & Mälardalens högskola & Handlingsplan för digitalisering (20I8) & I \\
\hline Handlingsplan & Lunds universitet & $\begin{array}{l}\text { Handlingsplan för utveckling av e-lärande vid Lunds } \\
\text { universitet 20I6-20I8 }\end{array}$ & 2 \\
\hline Handlingsplan & Mittuniversitetet & $\begin{array}{l}\text { Implementering av Mittuniversitetets utbildningsstrategi } \\
\text { 20II-20I5: Handlingsplan för e-lärande }\end{array}$ & 3 \\
\hline Policy & Umeå universitet & Umeå universitets policy för e-lärande (20I6) & 4 \\
\hline Policy & Högskolan Väst & Policy för flexibelt lärande och IKT-pedagogik & 5 \\
\hline Strategi & Karlstads universitet & $\begin{array}{l}\text { Strategi för utveckling av blended learning vid Karlstads } \\
\text { universitet (20I5) }\end{array}$ & 6 \\
\hline Vision & Kungliga Tekniska Högskolan & Vision för e-lärande vid KTH 20I6 & 7 \\
\hline
\end{tabular}

Analys

Under den diskursanalytiska processen framträder såväl mönster som variation och motstridigheter i och mellan texter (Jörgensen et al., 2000). Faircloughs (1989, 1992) analysverktyg består av tre dimensioner: analys av text (språkets egenskaper), analys av diskursiv praktik (textens kontext, hur den produceras, distribueras och konsumeras) och analys av diskursiva händelser som del av en social praktik. I analysprocessen ingår en beskrivning av texten med fokus på såväl innehåll som form, en tolkning av textens underliggande betydelser och förgivettaganden mot bakgrund av dess kontext och en förklaring av texten - dvs. sammankopplandet av de diskurser som framträder med den sociala verklighet i vilken de har uppstått. Jag läste inledningsvis igenom och kodades lärartexterna utifrån de tre huvudsakliga teman som lärarna hade förhållit sig till i sina reflekterande texter. Därefter vidtog en närläsning av texterna med särskilt fokus på vokabulär, retoriska grepp och modalitetsmarkörer ${ }^{6}$, i syfte att identifiera vilka olika diskurser som framträdde inom dessa teman. Processen styrdes av frågan: Hur konstrueras undervisning med digitala verktyg och vilka antaganden bygger dessa konstruktioner på? På samma sätt, och utifrån samma teman, analyserades därefter styrdokumenten. Slutligen genomfördes en kritisk jämförelse mellan texttyperna enligt Friesens (2008) ideologikritiska tolkningsmodell, där de konstruktioner av e-lärande och digitalisering av utbildning som kunde identifieras i

2 "Genre of governance" (Fairclough, 2003, s. 32).

3 Den publicerade lista som dessa dokument hämtats från innehåller också en länk till en webbsida som beskriver olika projekt som rör e-lärande vid Göteborgs universitet. Eftersom dessa dokument rör mindre delprojekt och snarare har karaktären av rapporter än strategiska dokument har de inte inkluderats i listan.

4 IT i Högre Utbildning.

5 För kodningen av alla texterna i materialet användes programmet NVivo.

6 Med modalitetsmarkörer avses adverb och hjälpverb som indikerar sannolikhet, nödvändighet eller önskvärdhet så som exempelvis bör, ska, kan, kanske, troligen, säkert. 


\section{Marita Ljungqvist}

styrdokumenten (som här representerar dominerande kunskapskällor i bemärkelsen att de sätter upp ramar för universitetslärares praktik) undersöktes mot bakgrund av de konstruktioner som kunde identifieras i lärartexterna (som här representerar alternativa, mindre inflytelserika kunskapskällor).

\section{Förförståelse}

Diskursanalys som metod innebär att ett visst mått av subjektiv tolkning genomsyrar alla delar av analysprocessen och förutsätter att forskaren har någon form av tolkningsföreträde (Alvesson \& Sköldberg, 20I7). Det är således viktigt att tydliggöra hur den egna förförståelsen kan ha spelat roll för resultatet. Jag har under flera år arbetat som pedagogisk utvecklare med särskilt intresse för e-lärande och i mitt arbete mött såväl lärare som personer på ledningspositioner som uttryckt egna föreställningar kring detta område. Mina förkunskaper har bidragit till att jag har kunnat styrka exempelvis en hög förekomst av liknande utsagor i materialet med egna erfarenheter av hur lärare talar om e-lärande. För att undvika att analysen bekräftade min förförståelse även när innehållet sade något annat, har jag genom analysprocessen kontinuerligt prövat olika sätt att tolka utsagorna och framför allt vinnlagt mig om att min slutliga tolkning av dem stöds av den omgivande texten.

\section{Etiska överväganden}

De reflektionsuppgifter som lärarna svarade på utgjorde obligatoriska uppgifter på kursen. De utformades i samband med kursplaneringen och inte i syfte att få ut forskningsdata. I enlighet med etikprövningslagen var forskningsetisk prövning inte nödvändig för denna studie, men enligt forskningsetisk praxis tillfrågades lärarna om deras reflekterande texter fick användas som analysmaterial i denna studie. Frågan ställdes efter att texterna hade lämnats in, mot slutet av kursen, och deltagande var frivilligt. $15^{7}$ lärare gav sitt medgivande genom att fylla i en samtyckesblankett. I samband med detta klargjordes också syftet med studien. Lärartexterna avidentifierades före analysen och namn som används i citat är fingerade.

\section{RESULTAT}

Jag kunde identifiera fyra övergripande diskurser i båda texttyperna. Jag har valt att benämna dessa Effektivitetsdiskursen, Lärandediskursen, Kompetensdiskursen samt Problematiseringsdiskursen. En diskurs, som jag har valt att kalla Oundviklighetsdiskursen, framträdde tydligt endast i styrdokumenten. Dessa diskurser och deras relation till temana målsättningar, förutsättningar och process för digitalisering av undervisning beskrivs nedan, där kursiveringarna i de illustrerande citaten indikerar för analysen särskilt relevanta uttryck. Därefter sammanfattas karaktären på diskurserna utifrån de tre temana i en översiktstabell.

\section{Effektivitetsdiskursen}

\section{Lärartexter}

En vanligt förekommande diskurs i lärarnas reflektioner som rör syften och målsättningar med att undervisa med digitala verktyg handlar om effektivitet, i bemärkelsen att göra undervisningen mer effektiv och därmed mer kvalitativ. Jeanette (c) skriver:

7 Totalt deltog 24 lärare i kursen. Det relativt låga antalet lärare som gav sitt medgivande kan bero på att endast 19 kursdeltagare var närvarande vid det kurstillfälle då blanketten delades ut. 
Jag vill kunna lyfta ut moment ur klassrummet, som jag tycker är viktiga eller svåra (och därför behöver kunna repeteras), men som egentligen inte tjänar på att jag tar upp dem muntligt när vi träffas. Ibland har jag för mycket att säga och prioriterar då bort mer aktiva moment.

Föreläsningsformatet å andra sidan konstrueras av flera som konservativt och ineffektivt. Henrik (c) menar t.ex. att ett av syftena med deras kursprojekt är att "frigöra tid från traditionella och slentrianmässiga undervisningsformer" och Staffan (c) att videoföreläsningar kan "ersätta traditionella föreläsningar, antingen som kostnadsbesparing eller för att frigöra resurser till mer handledning". Här finns dock också utrymme för en motsatt diskurs. Sofia (b) skriver exempelvis att föreläsningen kan vara en "alldeles utmärkt" pedagogisk form och att hennes lärarlag vill använda verktygen för att komplettera den.

När det gäller förutsättningarna för digitalisering av undervisningen framträder en annan bild där det arbetet framställs som tidskrävande snarare än tidsfrigörande. I utsagorna används verbfraser som uttrycker tvång och krav och indikerar svårighet att hinna med arbetet. Eva (a) skriver att deras planerade förändringar "måste rymmas inom nuvarande (eller lägre...) budget i form av lärartimmar" och Henrik (c) att hans "största problem är att hitta tid att testa och integrera dessa digitala verktyg i undervisningen". Bo (3) menar att ökad effektivitet inte är ett argument för att digitalisera undervisningen:

Digitala verktyg kräver också tid. Det är svårt att implementera digitala verktyg så att tid sparas, det är andra parametrar som måste styra.

Styrdokument

I flera av styrdokumenten är effektivitetsdiskursen central. Exempelvis beskrivs användningen av digitala verktyg för undervisningen som ett sätt att erbjuda studenterna mer kvalitetstid med sin lärare genom att de kan "frigöra tid för reflektion och kreativitet" (6) och skapa "ökad och mer kvalitativ samverkan mellan lärare och studenter samt studenter sinsemellan" (7), men också som ett sätt att effektivisera lärarnas arbetsvardag genom att de kan "underlätta lärarnas arbete" (7) samt "förenkla administrationen och frigöra tid" (I). Syften med att använda digitala undervisningsverktyg konstrueras här i metaforiska termer som har med frihet och lätthet att göra. Diskursen om undervisning med digitala verktyg som tidskrävande är nästan helt obefintlig i styrdokumenten, men anges i ett av dem som en hämmande faktor som skulle kunna undvikas genom bättre stödfunktioner:

Att utveckla nya undervisningsformer och material tar tid i en redan pressad situation för lärarna. De viktigaste grundfunktionerna och IT-systemen i en lärares vardag måste vara välfungerande och det måste finnas tillgänglig support. (I)

\section{Lärandediskursen}

\section{Lärartexter}

Omsorg om studenterna och vikten av att studenternas lärande stärks genom de föreslagna ändringarna i kurserna uttrycks på flera ställen i lärarnas texter. I relation till målsättningar finner vi verbfraser som konstruerar undervisning med digitala verktyg som främjande för studenters lärande som exempelvis: "stimulera studenternas engagemang i kursen och öka lärandet" (Carina [a]), "öka studenternas förmåga att bli mer självständiga i sitt lärande" (Henrik [b]), "skapa möjligheter som bidrar till studenternas lärande" (Bengt [b]) och "underlätta för studenternas planering" (Bo [c]). 
Samtidigt beskriver flera lärare en oro inför hur de planerade förändringarna ska tas emot av studenterna, kanske" som märkliga inslag som upptar deras tid eller helt enkelt som något 'tramsigt" (Sofia [c]). I själva verket kan studenterna "ha en skepsis mot webbaserade hjälpmedel, och en del vill ha traditionella föreläsningar" menar Anders (a). Monika (a) skriver:

Hur kommer studenterna att reagera om man tex. byter ut en föreläsning mot en videoföreläsning, eller ställer krav på ett de ska vara förberedda inför kursmoment. Hur kommer de reagera om de under en föreläsning förväntas vara aktiva själva - att de istället för att matas med kunskap förväntas hitta kunskapen själva?

Genom att ställa sig öppna frågor - som får stå obesvarade - antyder Monika en ängslan rörande effekterna av de nya undervisningsformerna. Verben mata(s) (med kunskap) och förvänta(s) kontrasterar en tidigare, mer kravlös situation mot en framtida situation, som innebär (nya) krav på studenterna.

Styrdokument

Liksom i lärartexterna identifieras i styrdokumenten en diskurs där målsättningen är att e-lärande ska främja studenters lärande. Digitaliseringen antas kunna ge "förbättrade resultat, ökad prestationsgrad" (7) samt kunna "stötta och utveckla lärandet och optimera det mänskliga mötet" (I). Ett dokument uppger att informations- och kommunikationsteknologi "kan utgöra ett verktyg i arbetet med breddad rekrytering och breddad genomströmning" (5) och ett annat att lärplattformar och digitala system "kan användas för att utveckla lärande, undervisning och examination" (2). Ett par av texterna kopplar målsättningarna med digitalisering av utbildningen till studenternas önskemål och förväntningar. Dessa texter uttrycker optimism och säkerhet rörande sådana önskemål i utsagor som: "[ $t$ ]illgängligheten till information och ett växande utbud av utbildningsmöjligheter påverkar studenternas förväntningar på öppenhet och val av studiestrategier" (6), "studenterna [är] redan 'digital natives', dvs. uppvuxna med digitala verktyg" (ibid.) och "[s]tudenter har i viss mån ändrat beteenden och tillgodogör sig i högre grad information visio-auditivt istället för skriftligt" (I).

\section{Kompetensdiskursen}

Lärartexter

Förutsättningarna för att kunna undervisa med digitala verktyg handlar inte bara om att ha tillräckligt med tid utan också att ha tillräcklig kompetens. Förberedelserna inför utbildningsförändringarna konstrueras i lärarnas texter som kompetenskrävande. Carina (b) uttrycker en oro över att det egna tekniska kunnandet inte ska räcka till:

Jag känner en viss osäkerhet om min och lärarlagets digitala kompetens kan utvecklas så att jag känner mig helt bekväm med att använda dessa digitala verktyg. När vi nu skulle spela in den lilla filmsnutt på kursen, var det många saker som fallerade och som vi behövde hjälp med längs vägen.

Några lärare beskriver en otrygghet i att arbeta med digitala medier som inte är direkt kopplad till teknisk kompetens. Jeanette (a) beskriver det exempelvis som en utmaning att "våga ställa oss framför kameran", och i en senare reflektionstext fortsätter hon att uttrycka osäkerheten inför just detta moment - trots att hon kommer från en miljö där digitala tjänster ofta används 
som verktyg i både undervisning och forskning: "Jag drar mig för att spela in filmerna ... känns lite obekvämt att vara den som testar nya arbetssätt" (Jeanette [c]).

Styrdokument

Även i styrdokumenten konstrueras digitaliseringen av undervisning som kompetenskrävande, men med fokus på lösningar och att kunna ge de rätta förutsättningarna för arbetet. Detta uttrycks framför allt i aktiva verbfraser. I en text uttrycks ett behov av att "göra en översyn av universitetets högskolepedagogiska kursutbud med särskilt fokus på progression i utveckling av lärarnas pedagogiska kompetens" (2). I ett annat dokument anges att "hela lärarkåren ska nå en högt didaktisk kvalificerad kompetens att integrera digital teknik i lärmiljön" (6). Samtidigt som kompetensutvecklingen framställs som oundviklig och tvingande genom användningen av hjälpverbet $s k a$, vidhålls i samma text att makten - och ansvaret - för att genomföra arbetet ändå ligger hos lärarna: "[d] et är lärarna som måste driva den pedagogiska utvecklingen av kurserna som de ansvarar för", medan lärosätet har en nödvändig (uttryckt genom hjälpverbet behöver) uppgift i att övertyga dem om att det är det rätta: "Stödorganisationen behöver också vara proaktiv och hämta in, prova ut och visa upp nya möjligheter."

\section{Problematiseringsdiskursen}

\section{Lärartexter}

Lärarna ombads att beskriva arbetsprocessen i lärarlaget och textinnehållet består av samarbetet med kollegorna, förklaringar till de val som görs under arbetets gång, tankar kring den egna lärarrollen, reflektioner kring implementeringen av det egna projektet och förhoppningar om utfallet. Flera texter beskriver hur planen långsamt växer fram i diskussionerna. "Vi resonerade fram och tillbaka vilka begrepp som var viktiga och varför de var viktiga" skriver Carina [a]). Jeanette (a) berättar:

[E]fter vår första träff efter första kurstillfället har vi landat $i$ en gemensam bild och tidsplan. Det var nog inte det att vi ville så olika egentligen, utan snarare att vi sett olika saker.

Ibland uppstår motsättningar mellan kollegorna, men det finns en vilja att komma överens:

Jag upplever att diskussionerna inom lärarlaget till en början var väldigt spretiga .... Men ju mer vi samtalade, desto mer synkade blev våra idéer och vi kunde formulera mål som vi tror att vi tillsammans skulle kunna genomföra. (Monika [a])

De metaforiska uttryck som används i texterna för att beskriva vad som hände under planeringsmöten med kollegorna; resonera fram och tillbaka, landa $i$, en gemensam bild, se olika saker, spretig och synkad illustrerar den sammansatta och komplexa karaktär som den kollegiala förändringsprocessen kan innebära.

Eva (c) förklarar hur hon tänker kring planerandet av hennes lärarlags projekt:

Man får ta en liten bit i taget. Lägga in en enda liten quizz och framför allt försöka följa upp hur studenterna faktiskt använder denna.

Verbfraserna i citatet indikerar försiktighet, noggrannhet och ett prövande förhållningssätt till förändringsprocessen. 
Styrdokument

I styrdokumenten finns några utsagor som åtminstone implicit pekar på vikten av att processen med att planera digitala undervisningsmoment tillåter eftertänksamhet och reflektion. I ett dokument framhålls att strukturerna för utbildningsplanering ska göra det möjligt för lärare "att fundera över hur ett ökat inslag av digitala verktyg påverkar den analoga undervisningen samt att välja ut de digitala och analoga inslagen på ett genomtänkt sätt" (6). Ett annat exempel på detta är:

Handlingsplanen betonar även vikten av att skapa fysiska och digitala miljöer som gör det möjligt att arbeta utforskande, att samarbeta och att genomföra utveckling i mindre piloter för att lära och dela erfarenheter. (I)

Användningen av verb som fundera, utforska och lära indikerar att förändringar som rör digitalisering av utbildningen bör ske på ett genomtänkt sätt. Den komplexitet, försiktighet och eftertänksamhet som lärarna beskriver kring frågorna om varför, i vilken utsträckning och på vilka sätt digitala verktyg ska användas syns dock inte i samma grad i styrdokumenten.

\section{Oundviklighetsdiskursen}

\section{Lärartexter}

I lärarnas texter framkommer inte tydligt ett förhållningssätt till digital undervisning som nödvändig eller oundviklig. Bengt (2) skriver om lärarlagets diskussioner:

[E]n fråga har hela tiden återkommit: varför ska vi ändra något som uppenbarligen fungerar? ... Samtidigt upplever jag att vi alla någonstans inser att vi bör möta studenterna med de verktyg som de är vana vid att använda och rimligen kommer att använda $i$ arbetslivet. Sedan kan jag inte låta bli att tilltalas lite av tanken på att det kan vara sunt att ibland vara lite motvalls och inte för enkelt, för snabbt och för lättvindigt anamma alla de möjligheter som står till buds ...

Bengt beskriver motstridiga tankar kring behovet av digitalisering. Å ena sidan uttrycks en uppfattad rekommendation vad gäller studenternas behov genom hjälpverbet bör. $\AA$ andra sidan indikerar Bengt genom adjektivet motvalls och adverbet för (enkelt, snabbt, lättvindigt) ett försiktigt kritiskt förhållningssätt till det urskillningslösa accepterande av utvecklingen som implicit förutsätts vara den rådande normen.

Styrdokument

I lärosätenas styrdokument konstrueras i flera fall den process som digitalisering av undervisning innebär som självklar och nödvändig i dagens samhälle. Ett universitet beskriver bakgrunden till sin policy på följande sätt: "Det pågår idag en explosionsartad utveckling inom digital teknik, sociala medier och kommunikation vilket skapar både högre krav och nya möjligheter för en kunskapsbärande organisation" (5). Ett universitets uttalade mål är att "e-lärande blir en integrerad del $i$ all utbildningsverksamhet" (4). I ett styrdokument fastslås att lärosätet "ska verka för en ökad användning av e-lärande och digitalt stöd för undervisning och examination" (2), i ett annat anges som ett mål att universitetet i fråga "ska vara erkänt framgångsrikt inom e-lärande, såväl bland studenter och arbetsliv" (3). Den snabba tekniska utvecklingen konstrueras i utdragen som en kraft som universiteten inte kan vika undan för, digitaliseringsprocessen som oundviklig och digital undervisning som en aktivitet som med nödvändighet bör spridas, öka och utgöra ett tecken på excellens. 
I några texter framhålls vikten av lärarnas positiva inställning till att undervisa med digitala verktyg för att visionerna som beskrivs i dokumenten ska förverkligas: "En övergångsfas underlättas om lärare och studenter är öppna för att tänka om och pröva nya vägar" (6). De metaforiska uttryck som används här beskriver nytänkandet som något positivt. Även här finns en antydan om oundviklighet: det blir lättare om lärare och studenter inte kämpar emot utvecklingen.

En av de stora utmaningarna inom högre utbildning är variationen i pedagogisk digital kompetens hos lärarna. Det handlar dels om begränsningar i tekniska färdigheter och nyttjande av digitala resurser och dels om förhållningssätt gentemot ny teknik för undervisning och lärande. Bilden känns igen från vårt lärosäte, ny teknik kan utgöra en hög tröskel för lärare och studenter som är oerfarna när det gäller e-lärande. (4)

Förhållningssätt gentemot ny teknik beskrivs i utdraget ovan som icke önskvärt, en utmaning. Tröskelmetaforen signalerar att utmaningen i första hand handlar om ett negativt förhållningssätt som kan förstås som kopplat till bristande förmåga.

\section{Sammanfattning av resultatet}

I tabellen nedan sammanfattas karaktären på de diskurser som framträtt vid analysen av texterna utifrån undersökningens tre övergripande teman målsättningar, förutsättningar och process i relation till digitalisering av undervisning.

\begin{tabular}{|c|c|c|c|}
\hline ANALYSFRÅGOR & Lärartexter & Styrdokument & DISKURSER \\
\hline \multirow{3}{*}{$\begin{array}{l}\text { Hur konstrueras målsätt- } \\
\text { ningar för och syften med } \\
\text { användningen av digitala } \\
\text { verktyg i undervisningen? }\end{array}$} & främjar studenters lärande & främjar studenters lärande & Lärandediskursen \\
\hline & effektiviserar undervisningen & $\begin{array}{l}\text { effektiviserar undervisningen } \\
\text { och lärarnas arbete }\end{array}$ & Effektivitetsdiskursen \\
\hline & $\begin{array}{l}\text { Oro: påverkar studenternas } \\
\text { upplevelse negativt? }\end{array}$ & $\begin{array}{l}\text { Förvissning: påverkar studen- } \\
\text { ternas upplevelse positivt! }\end{array}$ & Lärandediskursen \\
\hline \multirow{2}{*}{$\begin{array}{l}\text { Hur konstrueras förut- } \\
\text { sättningar för använd- } \\
\text { ningen av digitala verktyg } \\
\text { i undervisningen? }\end{array}$} & arbetet är tidskrävande & stödorganisationen är viktig & $\begin{array}{l}\text { Effektivitetsdiskursen } \\
\text { Kompetensdiskursen }\end{array}$ \\
\hline & $\begin{array}{l}\text { kompetenskrävande } \\
\text { - problemfokuserat }\end{array}$ & $\begin{array}{l}\text { kompetenskrävande } \\
\text { - lösningsorienterat }\end{array}$ & Kompetensdiskursen \\
\hline \multirow{2}{*}{$\begin{array}{l}\text { Hur konstrueras proces- } \\
\text { sen som undervisning och } \\
\text { planering av undervisning } \\
\text { med digitala verktyg } \\
\text { innebär? }\end{array}$} & $\begin{array}{l}\text { präglas av komplexitet, } \\
\text { osäkerhet }\end{array}$ & $\begin{array}{l}\text { präglas av oundviklighet, } \\
\text { övertygelse }\end{array}$ & $\begin{array}{l}\text { Problematiseringsdiskursen } \\
\text { Oundviklighetsdiskursen }\end{array}$ \\
\hline & $\begin{array}{l}\text { uttrycker försiktighet, } \\
\text { eftertänksamhet }\end{array}$ & $\begin{array}{l}\text { efterlyser positiv inställning } \\
\text { hos lärarna }\end{array}$ & $\begin{array}{l}\text { Problematiseringsdiskursen } \\
\text { Oundviklighetsdiskursen }\end{array}$ \\
\hline
\end{tabular}

\section{DISKUSSION}

Kontexten för de två texttyper som har analyserats i denna studie skiljer sig från varandra och analysprocess och resultat måste ställas mot bakgrund av att de tillhör två olika instanser av diskursiv praktik. Vilken genre en text tillhör påverkar skribentens val av ord och uttryck men också vilken information som anses vara relevant att förmedla. Man kan se genrer som diskursiva utrymmen som inte bara reglerar och organiserar innehåll utan där aktörer också konstruerar situationer i överenstämmelse med särskilda ideologier (Collin, 20I2). Som läsare förväntar vi oss sannolikt att ett styrdokument ska rekommendera och peka ut en tydlig riktning - övertyga läsaren (Nicoll \& Edwards, 2004, s. 45) - medan en reflekterande text kan dra åt olika håll, 


\section{Marita Ljungqvist}

innehålla fler kritiska element ${ }^{8}$, och i högre grad bestå av utsvävande och begrundande passager. Samtidigt bör man kunna förutsätta att de policytexter som ska rama in universitetslärares praktik tar hänsyn till den praktiska verklighet, de villkor och de behov som är relevanta för denna målgrupp. Utifrån en sådan utgångspunkt blir det viktigt att synliggöra de sanningsanspråk som görs i dokumenten och ställa dessa i relation till andra, mindre dominerande, anspråk på att beskriva denna praktik.

Samtidigt som det finns likheter mellan lärarnas beskrivningar och styrdokumentens utsagor exempelvis kunde jag i båda identifiera en betoning på vikten av lärarnas upplevda kompetens skiljer sig i en del fall karaktären på diskurserna i de två texttyperna tydligt åt. En del utsagor i styrdokumenten står explicit eller implicit i motsättning till lärarnas texter. Ett sådant exempel är hur användning av digitala verktyg konstrueras i förhållande till arbetstid. På lärosätesnivå är den centrala anledningen till digitalisering av utbildning att kunna frigöra tid och effektivisera, medan lärarna beskriver tid som den centrala förutsättningen för att kunna undervisa med digitala verktyg. Att införandet av digital undervisning förknippas med tidskrävande processer har också bekräftats i ett flertal andra studier (Benson, Anderson \& Ooms, 20II; Humbert, 2007; Lloyd et al., 20I2; Ocak, 20II; Vaughan, 2007).

Ett annat exempel är hur digitalisering av undervisning konstrueras i relation till nödvändighet. Styrdokumenten beskriver utveckling av undervisning med digitala verktyg i nästan alltigenom positiva ordalag och som en oundviklig och nödvändig förändring av verksamheten. Undervisning med digitala verktyg konstrueras som studentanpassat och tidsenligt. Texterna innehåller förgivettaganden om att lärare idag ägnar sig åt arbetsuppgifter som inte underlättar för lärande, att det finns ett behov av att förändra tidigare arbetssätt och att stödresurser och kunskapsspridning underlättar för att lärarna ska kunna genomföra detta. Att lärarna inte ger uttryck för denna oundviklighet skulle kunna bero på kontexten för texternas produktion. Samtidigt har instruktionerna till reflektionsuppgifterna möjliggjort för reflektioner inte bara kring de egna kursprojekten utan också mer generella aspekter av digitalisering, och därmed sannolikt inte utgjort ett hinder för att sådana antaganden skulle ha kunnat uttryckas i texterna. Lärarna kan också antas ha en i grunden positiv inställning till e-lärande - eftersom de har valt att gå en kurs om undervisning med digitala verktyg - men uttrycker ändå en förhållandevis komplex relation till digitalisering, och införandet av digitala undervisningsmoment ses inte som den enda rätta lösningen. De beslut som lärarna tar påverkas av diskussioner med kollegor, omsorgen om studenterna och den egna pedagogiska grundsynen, där man vill skynda långsamt. Lärarna vill värna om de delar av undervisningen som redan fungerar väl, även om de är mer "traditionella", och man uttrycker farhågor kring att studenter skulle kunna reagera negativt på digitala läraktiviteter och ökat ansvar i samband med detta. Medan lärarna uttrycker en viss osäkerhet kring om förändringarna kommer att få de effekter som eftersträvas präglas styrdokumenten alltså av övertygelse. Oundviklighetsdiskursen har noterats av andra forskare. Exempelvis talar Nardi och O’Day om "the rhetoric of inevitability" (I999, s. I7) som präglar det offentliga samtalet kring digital utveckling. Clegg et al. (2003) menar att tendenser som i politiska kontexter beskrivs som "oundvikliga resultat av en viss utveckling" (exempelvis globalisering) i själva verket ofta är effekten av de handlingar som statsmakterna utför i sina försök att skapa just dessa förhållanden. I förlängningen får oundviklighetsdiskursen betydelse för lärarnas praktik. I Johnsons (20I2) studie uppfattade lärarna att de satsningar som deras lärosäten gjorde

8 För en lista över och beskrivning av olika beståndsdelar som kan ingå i en akademisk reflekterande text, se t.ex. Ryan (2011). 
på digitalisering av undervisningen hade underliggande marknadsföringsmässiga och ekonomiska motiv som de inte själva ställde sig bakom. Samtidigt kände de sig indirekt pressade att "följa med strömmen".

\section{Studiens begränsningar}

Studien har några begränsningar. Vilka lärarna i studien är som individer - ålder, kön och disciplinär tillhörighet exempelvis - skulle möjligen kunna ha en betydelse för lärartexternas utformning och innehåll. Styrdokumenten kommer från flera lärosäten för att ge ett fylligare empiriskt material inom den genren, medan lärartexterna har producerats vid ett enda av dessa. Kanske skulle reflekterande texter skrivna av lärare vid ett av de andra lärosätena se annorlunda ut. Jag har här utgått ifrån att styrdokumenten tillsammans representerar en nationell syn på fenomenet digitala verktyg i undervisningen som kan sägas både utgöra och påverka det sammanhang som lärarna verkar i.

\section{Vidare forskning}

Denna artikel avser att inspirera till vidare forskning som kritiskt granskar det komplexa förhållandet mellan å ena sidan lärares och studenters förhållningssätt till "digitaliseringen av utbildningen" och den praktik som de verkar i, och å andra sidan de föreställningar som presenteras av företrädare för universitetsledningar och andra organisationer med relevans för högre utbildning. Detta är särskilt viktigt med tanke på att de senare har en avgörande betydelse för utformningen av den verksamhet där såväl lärare som studenter utför sitt dagliga arbete.

\section{REFERENSER}

Alvesson, M. \& Sköldberg, K. (2017). Tolkning och reflektion: vetenskapsfilosofi och kvalitativ metod. Lund: Studentlitteratur AB.

Benson, V., Anderson, D. \& Ooms, A. (2011). Educators' perceptions, attitudes and practices: blended learning in business and management education. Research in Learning Technology, 19(2), 143-154. https:// journal.alt.ac.uk/index.php/rlt/article/view/838

Bigum, C., Bulfin, S. \& Johnson, N. F. (2015). Critical Is Something Others (Don't) Do: Mapping the Imaginative of Educational Technology. I S. Bulfin, N. F. Johnson \& C. Bigum (Red.), Critical Perspectives on Technology and Education (ss. 1-13). New York, NY: Palgrave Macmillan. https://www.researchgate. net/publication/301223193_Critical_Perspectives_on_Technology_and_Education

Blin, F. \& Munro, M. (2008). Why hasn't technology disrupted academics' teaching practices? Understanding resistance to change through the lens of activity theory. Computers and Education, 50, 475-490. http://www.sciencedirect.com/science/article/pii/S0360131507001194

Bulfin, S., Henderson, M., Johnson, N. F. \& Selwyn, N. (2014). Methodological capacity within the field of "educational technology" research: an initial investigation. British Journal of Educational Technology, 45(3), 403-414. https://doi.org/10.1111/bjet.12145

Clegg, S., Hudson, A. \& Steel, J. (2003). The Emperor's New Clothes: Globalisation and e-learning in Higher Education. British Journal of Sociology of Education, 24(1), 39-53. https://doi.org/10.1080/ 01425690301914

Collin, R. (2012). Genre in Discourse, Discourse in Genre: A New Approach to the Study of Literate Practice. Journal of Literacy Research, 44(1), 76-96. http://journals.sagepub.com/doi/pdf/10.1177/ 1086296 X11431627

Creelman, A. (2018, 7 mars). Digitala strategier - uppföljning. http://ny.ithu.se/digitala-strategieruppfoljning/

Englund, C., Olofsson, A. D. \& Price, L. (2017). Teaching with technology in higher education: understanding conceptual change and development in practice. Higher Education Research \& Development, 36(1), 73-87. https://doi.org/10.1080/07294360.2016.1171300 


\section{Marita Ljungqvist}

Erlanson, E., Helgason, J. \& Henning, P. (2015). Den litteraturvetenskapliga nätundervisningens problem och möjligheter - rapport från ett kursutvecklingsprojekt. Paper presenterad på LU:s femte högskolepedagogiska utvecklingskonferens, Lunds universitet. https://www.lth.se/fileadmin/lth/genombrottet/ LUkonf2015/13_Erlanson_etal.pdf

Fairclough, N. (1989). Language and power. London: Longman.

Fairclough, N. (1992). Discourse and social change. Cambridge: Polity.

Fairclough, N. (2003). Analysing Discourse: Textual analysis for social research. London: Routledge.

Friesen, N. (2008). Critical Theory: Ideology Critique and the Myths of E-Learning. Ubiquity, June. https:// ubiquity.acm.org/article.cfm?id $=1386860$

Gee, P. J. (1999). An Introduction to Discourse Analysis: Theory and Method. London \& New York: Routledge.

Gouseti, A. (2010). Web 2.0 and education: not just another case of hype, hope and disappointment? Learning, Media and Technology, 35(3), 351-356. http://dx.doi.org/10.1080/17439884.2010.509353

Handlingsplan fördigitalisering (2018). Mälardalens högskola.http://www.mdh.se/polopoly_fs/1.109436!/ Menu/general/column-content/attachment/2437.pdf

Handlingsplan för utveckling av e-lärande vid Lunds universitet 2016-2018 (2015). Utbildningsnämnden, Lunds universitet. http://www.ahu.lu.se/fileadmin/user_upload/ahu/PDF/105_68_handlingsplan_ e-laerande_2016-18.pdf

Hardy, C., Phillips, N. \& Harley, B. (2004). Discourse Analysis and Content Analysis: Two Solitudes. Qualitative \& Multi-Method Research, 2, 19-22. https://zenodo.org/record/998649\#.WvleytNuZ24

Humbert, M. (2007). Adoption of blended learning by faculty: An exploratory analysis. I M. K. McCuddy, H. v. d. Bosch, W. B. Martz, A. V. Matveev \& K. O. Morse (Red.), The Challenges of Educating People to Lead in a Challenging World (Vol. 10). Dordrecht: Springer. https://doi.org/10.1007/978-1-40205612-3_21

Implementering av Mittuniversitetets utbildningsstrategi 2011-2015: Handlingsplan för e-lärande (2011). Mittuniversitetet. https://www.miun.se/SysSiteAssets/forvaltning/universitetsledningenskansli/ledningskanalen/utbildningstrategi/rapporter-och-uppfoljning-fr-o-m-2013/handlingsplan-e-laranderev20130924v1.pdf

Johnson, D. R. (2012). Technological Change and Professional Control in the Professoriate. Science, Technology, \& Human Values, 38(1), 126-149. http://journals.sagepub.com/doi/pdf/10.1177/ 0162243911430236

Jörgensen, M. W., Phillips, L. \& Vrå, B. (2000). Diskursanalys som teori och metod. Lund: Studentlitteratur AB.

Lloyd, S. A., Byrne, M. M. \& McCoy, T. S. (2012). Faculty-Perceived Barriers of Online Education. MERLOT Journal of Online Learning and Teaching, 8(1), 1-12. http://jolt.merlot.org/vol8no1/lloyd_0312.pdf

Munro, M. E. (2017). A decade of E-learning policy in higher education in the United Kingdom: a critical analysis. (Ed.D), University of Glasgow. http://theses.gla.ac.uk/7927/1/2016munroedd.pdf

Nardi, B. A. \& O’Day, V. (1999). Information ecologies: Using technology with heart: MIT Press.

Nicoll, K. \& Edwards, R. (2004). Lifelong learning and the sultans of spin: policy as persuasion? Journal of Education Policy, 19(1), 43-55. https://doi.org/10.1080/0268093042000182627

Ocak, M. A. (2011). Why are faculty members not teaching blended courses? Insights from faculty members. Computers \& Education, 56, 698-699. https://doi.org/10.1016/j.compedu.2010.10.011

Picciano, A. G. \& Dziuban, C. (2007). Blended Learning: Research Perspectives. https://onlinelearningconsortium.org/book/blended-learning-research-perspectives/

Policy för flexibelt lärande och IKT-pedagogik (2014). Högskolan Väst. https://www.hv.se/globalassets/dokument/styra-och-leda/policy-for-flexibelt-larande-och-ikt-pedagogik.pdf

Price, L. \& Kirkwood, A. (2014). Using technology for teaching and learning in higher education: a critical review of the role of evidence in informing practice. Higher Education Research \& Development, 33(3), 549-564. http://dx.doi.org/10.1080/07294360.2013.841643

Ryan, M. (2011). Improving reflective writing in higher education: a social semiotic perspective. Teaching in Higher Education, 16(1), 99-111. https://doi.org/10.1080/13562517.2010.507311 
Selwyn, N. (2011). Editorial: In praise of pessimism - the need for negativity in educational technology. British Journal of Educational technology, 42(5), 713-718. http://onlinelibrary.wiley.com/doi/10.1111/ j.1467-8535.2011.01215.x/epdf

Selwyn, N. (2015). Minding our language: why education and technology is full of bullshit...and what might be done about it. Learning, Media and Technology, 41(3), 437-443. http://dx.doi.org/10.1080/1743 9884.2015.1012523

Strategi for utveckling av blended learning vid Karlstads universitet (2015). Karlstads universitet. http://www. intra.kau.se/dokument/upload/C10B949704f5b20EC6KrFEF389D0/6_15Bilagastrategi.pdf

Ubell, R. (2016). Why Faculty Still Don't Want to Teach Online. Inside Higher Ed. https://www.insidehighered.com/news/survey/conflicted-views-technology-survey-faculty-attitudes

Umeå universitets policy för e-lärande (2016). Umeå universitet. https://www.aurora.umu.se/globalassets/ dokument/universitetsforvaltningen/kommunikationsenheten/nyhetsdokument/e-larandepolicy_20160405.pdf

Vaughan, N. (2007). Perspectives on blended learning in higher education. International journal on e-learning, 6(1), 81-94.

Vision för e-lärande vid KTH 2016 (2013). Kungliga Tekniska Högskolan. https://www.kth.se/polopoly_ fs/1.147445!/Menu/general/column-content/attachment/v2027sv\%20slutversion.pdf 